\title{
Regulation and action of fibroblast growth factor 17 in bovine follicles
}

\author{
M F Machado, V M Portela ${ }^{1}$, C A Price ${ }^{1}$, I B Costa, P Ripamonte ${ }^{2}$, R L Amorim ${ }^{3}$ and J Buratini Jr ${ }^{2}$ \\ Departamento de Reprodução Animal, Faculdade de Medicina Veterinária e Zootecnia, Universidade Estadual Paulista, Botucatu, São Paulo 18618-000, Brazil \\ ${ }^{1}$ Centre de recherche en reproduction animale, Faculté de médecine vétérinaire, Université de Montréal, St-Hyacinthe, Quebec J2S 7C6, Canada \\ ${ }^{2}$ Departamento de Fisiologia, Instituto de Biociências, Universidade Estadual Paulista, Rubião Júnior, Botucatu, São Paulo 18618-000, Brazil \\ ${ }^{3}$ Departamento de Clínica Veterinária, Faculdade de Medicina Veterinária e Zootecnia, Universidade Estadual Paulista, Botucatu, São Paulo, Brazil \\ (Correspondence should be addressed to J Buratini Jr; Email: buratini@ibb.unesp.br)
}

\begin{abstract}
Fibroblast growth factor 17 (FGF17) is a member of the FGF8 subfamily that appears to be relevant to folliculogenesis and oogenesis, as the prototype member FGF8 is an oocyte-derived protein that signals to cumulus cells. FGF8 has structural and receptor-binding similarities to FGF17, whose expression in the ovary has not been reported. In this study, we demonstrate localization of FGF17 protein to the oocyte of preantral follicles, and to the oocyte and granulosa cells of antral follicles. Real-time PCR demonstrated the presence of mRNA in oocytes and, to a lesser extent, in
\end{abstract}

granulosa and theca cells. FGF17 mRNA abundance was low in granulosa and theca cells from healthy follicles and increased significantly in atretic follicles. Addition of FSH or IGF-I to granulosa cells in vitro decreased FGF17 mRNA abundance, and treatment with FGF17 inhibited estradiol and progesterone secretion from granulosa cells in relation to control cultures without these additives. We conclude that FGF17 is a potential mediator of granulosa cell differentiation.

Journal of Endocrinology (2009) 202, 347-353

\section{Introduction}

Follicle development is under the control of gonadotropins, steroids, and a variety of locally produced peptides including fibroblast growth factors (FGFs; Webb et al. 2003). Several FGFs and their receptors (FGFR) have been detected in ovarian follicles, suggesting roles in the regulation of folliculogenesis (van Wezel et al. 1995, Berisha et al. 2004, Buratini et al. 2005a,b, 2007). The 22 known FGFs have been grouped into seven subfamilies with distinct receptor-binding properties. The FGFR proteins are encoded by five different genes, three of which, FGFR1, 2, and 3, undergo alternative splicing to produce two functional variants (B and C; Ornitz et al. 1996, Itoh \& Ornitz 2004). Paracrine roles within the follicle have been explored for FGF2 and for the FGF7 subfamily, containing also FGF10. FGF2, which is predominantly expressed by theca cells (Berisha et al. 2000), stimulates proliferation and inhibits steroidogenesis in both theca and granulosa cells (Lavranos et al. 1994, Vernon \& Spicer 1994, Spicer \& Stewart 1996, Nilsson et al. 2001). FGF7 and FGF10 are expressed in the theca cell layer but not in granulosa cells, and the receptor FGFR2B is predominantly expressed in granulosa cells (Parrott \& Skinner 1998, Berisha et al. 2004, Buratini et al. 2007). Both FGFs inhibit estradiol $\left(\mathrm{E}_{2}\right)$ secretion from cultured granulosa cells (Parrott \& Skinner 1998, Buratini et al. 2007).
Another subfamily that may be of interest for potential paracrine signaling is the FGF8 subfamily. In adult rodents, Fgf8 gene expression is largely confined to the oocyte (Valve et al. 1997), and was reported in oocytes as well as somatic follicle cells in cattle (Buratini et al. 2005b). FGF8 activates FGFR3C, which was found in theca and granulosa cells in cattle, and FGFR4, which was localized only to theca cells (Ornitz et al. 1996, Buratini et al. 2005b). Although the roles of the FGF8 subfamily in the control of the ovarian activity are still poorly understood, it has been recently shown that oocyte-derived FGF8 cooperates with bone morphogenetic protein 15 (BMP15) to promote glycolytic activity in cumulus cells in mice (Sugiura et al. 2007).

The FGF8 subfamily also contains FGF17 (Itoh \& Ornitz 2004), which also preferentially activates FGFR3C and FGFR 4 (Ford-Perriss et al. 2001, Zhang et al. 2006). FGF17 gene expression was first detected in the embryonic brain, and is most associated with neurogenesis (O'Leary et al. 2007) and skeletal development (Krejci et al. 2007). Very little is known about the pattern of expression of FGF17 in the reproductive system. mRNA encoding FGF17 was detected in human prostatic epithelial cells (Polnaszek et al. 2004), human placenta, and in mouse oocytes and embryos (Zhong et al. 2006).

The objective of the present work was to test the hypothesis that FGF17 is a candidate for paracrine signaling within the follicle. Specifically, we sought to localize FGF17 mRNA in follicular cell types, to determine whether mRNA 
expression is under the control of the major regulators of follicle development, FSH and insulin-like growth factor-I (IGF-I), and to gain insight into the potential role of FGF17 in the regulation of follicle steroidogenesis.

\section{Materials and Methods}

\section{Tissues}

Follicles of diameter $\geq 5 \mathrm{~mm}$ were dissected from the ovaries of adult cows (predominantly Nellore, Bos indicus) obtained in an abattoir local to the Sao Paulo State University campus in Botucatu and transported to the laboratory in saline on ice. Follicular fluid was aspirated, centrifuged, and frozen for progesterone $\left(\mathrm{P}_{4}\right)$ and $\mathrm{E}_{2}$ assays. The antral cavity was flushed repeatedly with cold saline, and granulosa cells were recovered by centrifugation at $1200 \mathrm{~g}$ for $1 \mathrm{~min}$ and pooled with the follicular fluid pellet. The remaining granulosa cells adhering to the follicle wall were removed by gently scraping with a blunt Pasteur pipette, and the theca layer was removed with forceps and washed in saline by repeated passages through a $1 \mathrm{ml}$ syringe. Samples were collected in Trizol (Invitrogen Life Technologies), homogenized with a Polytron, and submitted immediately to total RNA extraction according to the manufacturer's protocol.

Follicles were classed according to $\mathrm{E}_{2}: \mathrm{P}_{4}$ ratios of $>1$, $1-0 \cdot 01$, and $<0 \cdot 01$ (Ireland et al. 1994), which we defined as healthy, transitional, and highly atretic respectively (Grimes \& Ireland 1986). Mean follicle fluid steroid concentrations and follicle diameters for each follicle class are given in Table 1. Cross-contamination of theca and granulosa cells was tested by the detection of mRNA encoding cytochromes $\mathrm{P} 450$ aromatase (CYP19A1) and 17 $\alpha$-hydroxylase (CYP17A1) mRNA in each sample by PCR as described (Buratini et al. 2005b). The detection of CYP19A1 amplicons in theca samples or of CYP17A1 amplicons in granulosa samples indicated cross-contamination, and such samples were discarded.

Cumulus-oocyte complexes (grades 1 and 2; Leibfried \& First 1979) were aspirated from antral follicles $(2-8 \mathrm{~mm})$ collected at an abattoir, and oocytes were mechanically isolated by careful and repeated pippeting until no adhering

Table 1 Mean ( \pm S.E.M.) follicular fluid estradiol $\left(E_{2}\right)$ and progesterone $\left(\mathrm{P}_{4}\right)$ concentrations and follicle diameters of follicles classed as healthy, transitional, and atretic based on $\mathrm{E}_{2}: \mathrm{P}_{4}$ ratio

\begin{tabular}{|c|c|c|c|}
\hline & $\begin{array}{l}\text { Healthy } \\
(n=16)\end{array}$ & $\begin{array}{c}\text { Transitional } \\
(n=17)\end{array}$ & $\begin{array}{l}\text { Atretic } \\
(n=10)\end{array}$ \\
\hline Estradiol (ng/ml) & $540 \pm 249 *$ & $16 \pm 3^{+}$ & $0 \cdot 3 \pm 0 \cdot 1^{\neq}$ \\
\hline Progesterone (ng/ml) & $19 \pm 3 *$ & $44 \pm 7^{+}$ & $290 \pm 59^{\neq}$ \\
\hline Diameter (mm) & $9 \pm 1$ & $9 \pm 1$ & $8 \pm 1$ \\
\hline Diameter range $(\mathrm{mm})$ & $5-13$ & $6-11$ & 5-11 \\
\hline
\end{tabular}

Within rows, means with different superscripts are significantly different $(P<0 \cdot 05)$ cumulus cells could be observed under a stereomicroscope. Total RNA was extracted from pools of 20 oocytes with the RNeasy kit (Qiagen).

\section{Cell culture}

Granulosa cell culturing was performed as described (Gutiérrez et al. 1997) with modifications (Manuel Silva \& Price 2000). All materials were obtained from Invitrogen, except where otherwise stated. Follicles with a $\leq 5 \mathrm{~mm}$ diameter were dissected from ovaries of Bos taurus cows obtained at an abattoir local to the University of Montreal in St Hyacinthe, and transported to the laboratory in PBS at $35{ }^{\circ} \mathrm{C}$ containing penicillin $(100 \mathrm{IU} / \mathrm{ml})$ and streptomycin $(100 \mu \mathrm{g} / \mathrm{ml})$. Follicles with obvious signs of atresia (avascular theca, debris in antrum) were discarded. Cells were collected by repeatedly passing the follicle wall through a pipette, washed twice by centrifugation at $980 \boldsymbol{g}$ for $20 \mathrm{~min}$ each, and suspended in DMEM/F12 containing Hepes $(20 \mathrm{mM})$, sodium selenite $(4 \mathrm{ng} / \mathrm{ml})$, BSA $(0 \cdot 1 \%$; Sigma-Aldrich), penicillin $(100 \mathrm{IU} / \mathrm{ml})$, streptomycin $(100 \mu \mathrm{g} / \mathrm{ml})$, transferrin $(2.5 \mu \mathrm{g} / \mathrm{ml})$, non-essential amino acid mix $(1.1 \mathrm{mM})$, androstenedione $\left(10^{-7} \mathrm{M}\right.$ at the start of culture and $10^{-6} \mathrm{M}$ at each medium change), and insulin $(10 \mathrm{ng} / \mathrm{ml})$. Cell viability was estimated with $0 \cdot 4 \%$ trypan blue stain. Cells were seeded into 24-well tissue culture plates (Sarstedt, Newton, NC, USA) at a density of $10^{6} /$ well in $1 \mathrm{ml}$ medium. Cultures were maintained at $37^{\circ} \mathrm{C}$ in $5 \% \mathrm{CO}_{2}$ in air for 6 days, with $700 \mu \mathrm{l}$ medium being replaced every 2 days.

To determine the regulation of FGF17 mRNA expression, cells were stimulated with graded doses of FSH (AFP-5332B, NIDDK, Bethesda, MD, USA; 0, 0•1, 1, 10, and $100 \mathrm{ng} / \mathrm{ml}$ ) or IGF-I analog (LR3; Sigma-Aldrich; 0, 5, 10, 50, and $100 \mathrm{ng} / \mathrm{ml}$ ) starting on day 2 of culture. At the end of the culture period, cells were collected in Trizol and stored at $70{ }^{\circ} \mathrm{C}$ until RNA extraction. Data were derived from three independent cultures performed at different times.

To determine the potential role of FGF17, granulosa cells were treated with FSH $(10 \mathrm{ng} / \mathrm{ml})$ to stimulate FGFR $3 c$ mRNA levels (Buratini et al. 2005b) and with graded doses of FGF17 (PeproTech, Rocky Hill, NJ, USA) starting on day 2 of culture. To measure steroid secretion, the medium was removed for steroid assay on day 6 and stored at $-20^{\circ} \mathrm{C}$. The cells were lysed with $200 \mu \mathrm{l}$ of $1 \mathrm{M} \mathrm{NaOH}$ for $2 \mathrm{~h}$ followed by neutralization with $200 \mu \mathrm{l}$ of $1 \mathrm{M} \mathrm{HCl}$ for total cell protein measurement with the Bradford protein assay (Bio-Rad). These cultures were performed on three independent cultures performed at different times, and were performed several months after the FSH/IGF dose-response cultures.

\section{Reverse transcription (RT)-PCR}

Theca and granulosa cell RNA $(1 \mu \mathrm{g})$ samples were incubated

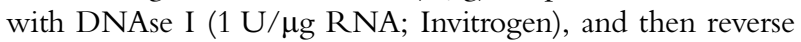
transcribed with SuperScript III (200 U/ $\mu$ l; Invitrogen) and oligo- $\mathrm{d}(\mathrm{T})$ primer. The RNA yield from pools of twenty oocytes was too low to be accurately quantified by 
spectrometry, so $8 \mu \mathrm{l}$ aliquots of RNA, corresponding approximately to five oocytes, were incubated with DNAse I (1 U/ sample; Invitrogen) to produce $10 \mu$ l of RNA solution, which is the maximum volume for the RNA sample in the reverse transcription (RT) protocol (SuperScript III, Invitrogen).

Primers for FGF17 mRNA were designed based on the predicted bovine sequences, and amplicons were sequenced to confirm identity. Relative real-time RT-PCR analysis was performed with an ABI 7500 using TaqMan Assay by Design (Applied Biosystems, Sao Paulo, Brazil) for the target gene (FGF17), as it provided a higher amplification efficiency in comparison with SYBR Green. As previous studies have shown that these two detection systems produce similar results for high abundance messages (Jeong et al. 2005), we used Power SYBR Green PCR Master Mix (Applied Biosystems) for housekeeping genes. Amplification efficiencies for target and housekeeping genes were similar. The primer sequences, fragment size, and annealing temperature for each gene are shown in Table 2. Reactions were optimized to provide maximum amplification efficiency for each gene. PCR was performed on $0.5 \mu \mathrm{l}$ cDNA in $25 \mu \mathrm{l}$ reaction volumes in duplicate, and the specificity of each PCR product was determined by melting curve analysis (for housekeeping genes) and confirmation of the amplicon size using electrophoresis with $2 \%$ agarose gels (for FGF17 and housekeeping genes). Negative controls (water replacing cDNA) were run in every plate. The relative expression of each target gene was calculated using the $\Delta \Delta C_{\mathrm{t}}$ method with efficiency correction (Pfaffl 2001); the control was a cDNA sample from each cell type analyzed. An initial analysis of FGF17 mRNA across follicle cell types was performed with glyceraldehyde3-phosphate dehydrogenase (GAPDH) as housekeeping gene, as this gene is expressed at similar levels in theca and granulosa cells (Buratini et al. 2005b). To select the most stable housekeeping gene for detailed analyses of each cell type, peptidylprolyl isomerase A (PPIA), GAPDH, and histone H2AFZ (H2AFZ) amplification profiles were compared using the geNorm applet for Microsoft Excel (medgen.ugent.be/ genorm; Ramakers et al. 2003); the most stable housekeeping genes were PPIA for theca cells and oocytes, GAPDH for granulosa, and $H 2 A F Z$ for cultured granulosa cells.

\section{Immunohistochemistry}

Bovine ovaries were collected from an abattoir, bisected, and fixed in paraformaldehyde. Fixed tissues were embedded in paraffin, and $3 \mu \mathrm{m}$ sections were placed on poly-L-lysinecoated slides. Sections were deparaffinized in xylene twice for $20 \mathrm{~min}$, and hydrated in successive 3 min washes in 95 and $85 \%$ ethanol. Antigen retrieval was achieved by incubating in $0.5 \mathrm{mM}$ Tris-EDTA $\mathrm{pH} 9.0$ at $96{ }^{\circ} \mathrm{C}$ for $30 \mathrm{~min}$. Endogenous peroxidase was quenched by incubation in methanol with $5 \%$ hydrogen peroxide for $10 \mathrm{~min}$, and then rinsed ten times in distilled water and twice for $5 \mathrm{~min}$ in $0.5 \mathrm{M}$ Tris $\mathrm{pH} 7 \cdot 4$. Slides were then incubated with polyclonal FGF17 antibody $(1.25 \mu \mathrm{g} / \mathrm{ml}$; 500-P152; PeproTech) for $2 \mathrm{~h}$ at room temperature in a humidified chamber. Slides were washed in $0.5 \mathrm{M}$ Tris $\mathrm{pH} 7 \cdot 4$, then incubated with HRPconjugated secondary antibody for $40 \mathrm{~min}$ (EnVision Dual Link System, Dako, Carpinteria, CA, USA). Immunostaining was revealed with liquid $\mathrm{DAB}\left(3,3^{\prime}\right.$ diamino benzidine; Dako), and sections were counterstained with Harris hematoxylin. Six to seven sections were examined from each of three ovaries. Negative controls were performed by preincubating FGF17 antibody with twice the concentration of recombinant FGF17 protein for $2 \mathrm{~h}$ at room temperature (2.5 $\mu \mathrm{g} / \mathrm{ml} ; 100-27$; PeproTech). The immunogen used for antibody production has at most $67 \%$ homology with other human FGFs. No bovine FGF8 family proteins are available, so it is not possible to test antibody specificity experimentally.

\section{Steroid assays}

$\mathrm{E}_{2}$ and $\mathrm{P}_{4}$ were assayed in follicular fluids using iodinated tracers and the antibodies furnished in the Third Generation Estradiol RIA and Progesterone RIA kit (Diagnostic Systems Laboratories Inc., Webster, TX, USA) respectively with a revised protocol (Buratini et al. 2005b). The standard curves and samples were diluted in PBS-gelatin. The intra- and inter-assay coefficients of variation (CV) were $7 \cdot 4$ and $13 \cdot 5 \%$ respectively for $\mathrm{E}_{2}$, and 6.8 and $7 \cdot 0 \%$ respectively for $\mathrm{P}_{4}$. The sensitivities of the assays were $0.3 \mathrm{ng} / \mathrm{ml}$ for $E_{2}$ and $0 \cdot 2 \mathrm{ng} / \mathrm{ml}$ for $\mathrm{P}_{4} \cdot \mathrm{E}_{2}$ was measured in conditioned medium in

Table 2 Details of primers used for real-time PCR

Sequence

Target

GAPDH

PPIA

$H 2 A F Z$

FGF17
F: $5^{\prime}$ ggc gtg aac cac gag aag tat aa $3^{\prime}$

R: $5^{\prime}$ CCC tCc acg atg cca aag t $3^{\prime}$

F: $5^{\prime}$ gCC atg gag cgc ttt gg $3^{\prime}$

R: $5^{\prime}$ cca cag tca gca atg gtg atc $t 3^{\prime}$

$\mathrm{F}: 5^{\prime}$ gag gag ctg aac aag ctg ttg $3^{\prime}$

R: $5^{\prime}$ ttg tgg tgg ctc tca gtc ttc $3^{\prime}$

F: $5^{\prime}$ ccg ggt gcg cat caa g $3^{\prime}$

R: $5^{\prime}$ gct tgc ccc tct tat tca tac aga $t 3^{\prime}$

Probe FAM $5^{\prime}$ ctg aga gtg aga aat ac $3^{\prime}$
Fragment size (bp)

119

65

74

62

$F$, forward primer; $R$, reverse primer. 
duplicate as described (Bélanger et al. 1990) without solvent extraction. Intra- and inter-assay CV were 6 and $9 \%$ respectively. $\mathrm{P}_{4}$ was measured in conditioned medium in duplicate as described (Lafrance \& Goff 1985) with mean intra- and inter-assay CV were $7 \cdot 2$ and $18 \%$ respectively. The sensitivity of these assays was 10 and 4 pg per tube for $E_{2}$ and $\mathrm{P}_{4}$, equivalent to 0.3 and $20 \mathrm{ng} / \mu \mathrm{g}$ protein respectively. Steroid concentrations in culture medium were corrected for cell number by expressing per unit mass of total cell protein.

\section{Statistical analysis}

The data were transformed to logarithms if not normally distributed. ANOVA was used to compare follicle size and intrafollicular steroid concentrations across follicle classes, to test the effect of follicle class on FGF17 mRNA abundance in granulosa cells, to test the effects of FSH and IGF-I on FGF17 mRNA levels in cultured granulosa cells, and to test the effect of FGF17 on steroid secretion from cultured granulosa cells. Means comparisons were performed with the Tukey-Kramer HSD test. Non-parametric ANOVA was used to test the effect of follicle class on FGF17 mRNA abundance in theca cells, and to compare FGF17 mRNA abundance across follicle cell types as data were not normally distributed even after transformation to logarithms. Means comparisons were performed with the Kruskal-Wallis test. Data are presented as means \pm s.E.M. Analyses were performed with JMP software (SAS Institute, Cary, NC, USA).

\section{Results}

Immunohistochemistry revealed the presence of FGF17 predominantly in oocytes and granulosa cells of preantral and antral follicles (Fig. 1). Staining was predominant in the nucleus of oocytes in preantral follicles, and was more intense in the cytoplasm of oocytes from antral follicles (Fig. 1A-C). Staining was weak in the theca cell layer, detected at background levels in deep ovarian stroma (Fig. 1E), and also clearly observed in the surface epithelium. Atretic follicles with only a few layers of granulosa cells and many pycnotic nuclei also stained strongly for FGF17 (Fig. 1D). No staining was observed when FGF17 antibody was preincubated with excess FGF17 (Fig. 1F).

A survey of FGF17 expression in follicle cells by real-time PCR showed the presence of mRNA in pooled oocytes and at comparatively low levels in both granulosa and theca cells. We initially compared FGF17 mRNA across follicle cell types using $G A P D H$ as housekeeping gene. Relative abundance was higher in oocytes $(51 \pm 14)$ compared with granulosa and theca cells $(0 \cdot 025 \pm 0 \cdot 008$ and $0 \cdot 005 \pm 0 \cdot 001$ respectively) from healthy and transitional follicles. A detailed assay of FGF17 in granulosa and theca cells collected from healthy, transitional, and atretic follicles showed that mRNA abundance was significantly higher in granulosa and theca cells from atretic follicles than from healthy or transitional follicles (Fig. 2). There was no effect of diameter on FGF17 expression within any of the health status classes.
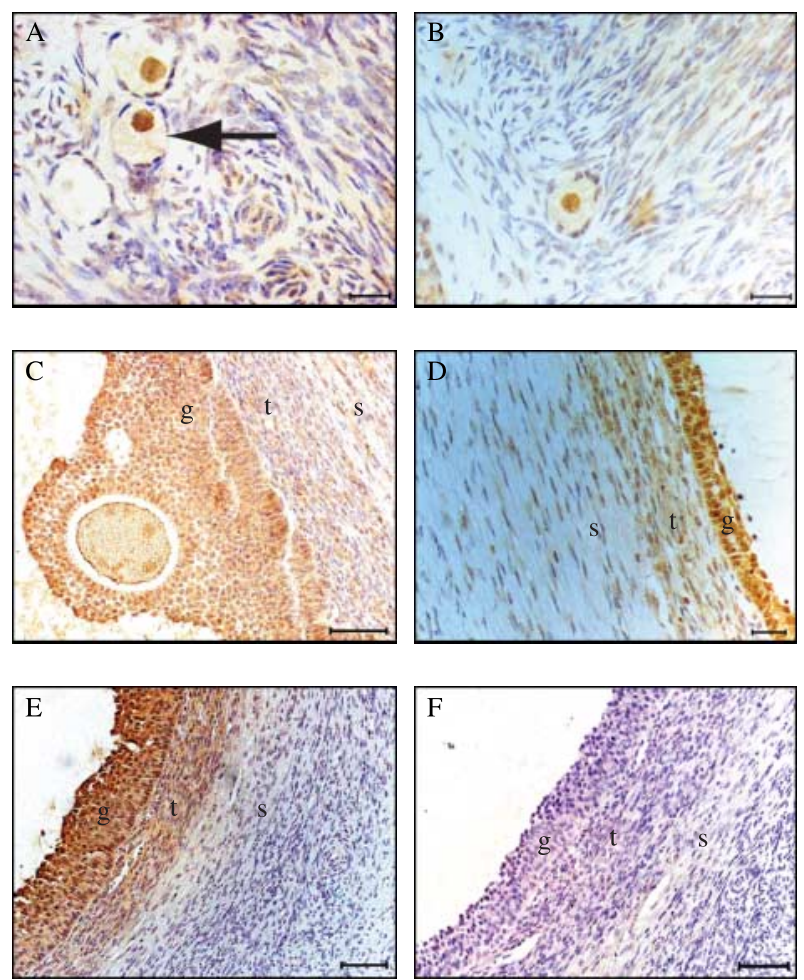

Figure 1 Immunohistological detection of FGF17 in bovine ovaries. Staining is observed in the oocyte of primordial (A, arrow), primary (B), and antral (C) follicles. The granulosa cell layer was well stained in healthy $(\mathrm{C}$ and $\mathrm{E})$ and atretic (D) antral follicles, whereas the theca layer was weakly stained. No staining was observed in the presence of excess FGF17 protein (F). Bars $=20 \mu \mathrm{m}(A, B$, and D), $30 \mu \mathrm{m}(\mathrm{C})$, and $50 \mu \mathrm{m}$ (E and $\mathrm{F}) . \mathrm{g}$, granulosa; t, theca; s, stroma.

As FGF17 protein and mRNA were detected in granulosa cells, we determined whether expression can be regulated by FSH and IGF-I. Cells were cultured in serum-free medium and treated for 6 days with graded doses of FSH or IGF-I. Both gonadotropic hormones significantly inhibited FGF17 mRNA abundance while increasing $E_{2}$ secretion (Fig. 3). Given this apparent inverse relationship between $\mathrm{E}_{2}$ and FGF17, we sought to determine whether FGF17 can regulate $\mathrm{E}_{2}$ secretion from granulosa cells. FGF17 inhibited $\mathrm{E}_{2}$ and $\mathrm{P}_{4}$ secretion from cultured granulosa cells in a dose-dependent manner (Fig. 4).

\section{Discussion}

These data demonstrate for the first time the expression of FGF17 protein and mRNA in the ovary. The most significant findings are the higher abundance of FGF17 mRNA in granulosa and theca cells of atretic follicles compared with healthy follicles, the inhibition of FGF17 mRNA abundance in granulosa cells by FSH and IGF-I, and the inhibitory effect of FGF17 on granulosa cell steroid secretion. These data point to an inhibitory role for FGF17 in follicular steroidogenesis and its involvement in the mechanisms controlling follicle atresia. 


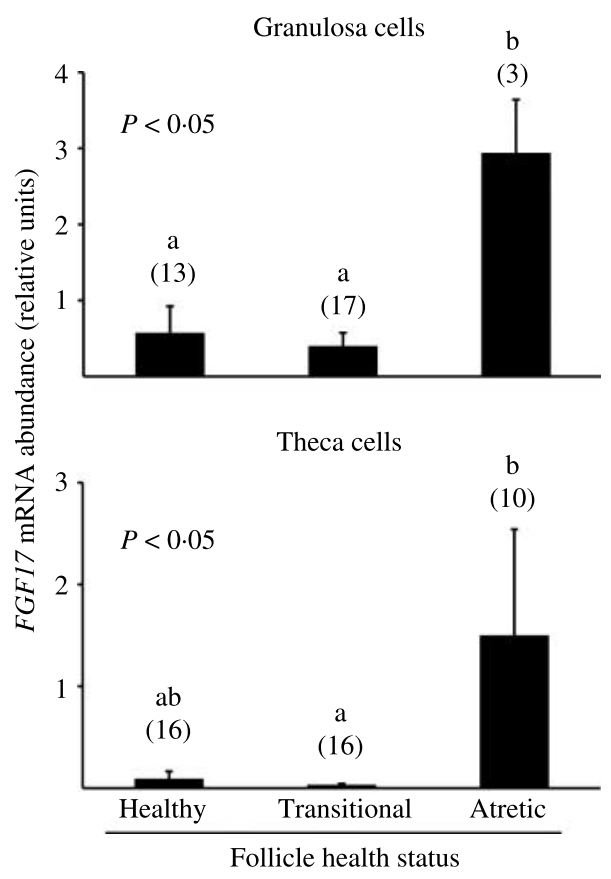

Figure 2 Follicular FGF17 mRNA abundance varies with follicle health. Follicles were classified as healthy, transitional, or atretic based on $E_{2}: P_{4}$ ratios in follicle fluid and RNA measured by realtime PCR in isolated granulosa and theca cells. Data are presented as mean $( \pm$ s.E.M. $)$ values relative to the housekeeping gene and to a calibrator sample present in all PCR runs, which were calculated using the $\Delta \Delta C_{\mathrm{t}}$ method with efficiency correction. Bars with different letters are significantly different $(P<0 \cdot 05)$. Numbers in parentheses denote the number of samples analyzed.

In the female reproductive system, FGF17 mRNA has been described only in isolated mouse oocytes and embryos (Zhong et al. 2006). In the present study, we describe FGF17 mRNA predominantly in oocytes, compared with lower expression in granulosa and theca cells. This conclusion is drawn from an analysis of relative expression (calculated as $\Delta \Delta C_{\mathrm{t}}$ value) in all three cell types using $G A P D H$ as housekeeping gene. This is based on the assumption that this housekeeping gene is expressed at similar levels in all three cell types, and our previous data have shown this to be valid for granulosa and theca cells (Buratini et al. 2005b). Analysing the same data with PPIA as housekeeping gene gave the same results; mRNA abundance was at least 100-fold greater in oocytes compared with granulosa and theca cells. This conclusion is consistent with the oocyte localization of the prototype member of this FGF subfamily, FGF8 (Valve et al. 1997, Buratini et al. 2005b, Sugiura et al. 2007). The higher expression of FGF17 in the oocyte does not imply that this cell is the predominant intrafollicular source of FGF17 as the number of somatic cells is greatly superior within the follicle, but rather suggests that oocyte-derived FGF17 may play a role in the mechanisms controlling cumulus cells differentiation. In fact FGF8 was shown to synergize with BMP15 to promote glycolysis in murine cumulus cells (Sugiura et al. 2007).
Other FGFs have been localized to the bovine oocyte, including FGF2 and FGF10 (van Wezel et al. 1995, Buratini et al. 2007), but this is not a FGF-wide phenomenon as FGF7 mRNA was readily detected in theca cells but not in oocytes (Buratini et al. 2007).

Protein was predominantly localized to the nucleus of oocytes in primordial and primary follicles, whereas in follicles at later stages of development, FGF17 protein was also clearly detected in the ooplasm. This suggests translocation of protein to the nucleus in oocytes, which is more apparent in primordial and primary follicles. Nuclear translocation of endogenous FGF has been reported for FGF1, -2 , and -3 (Zhan et al. 1992, Kiefer \& Dickson 1995, Sheng et al. 2004). FGF17 protein was also present in the granulosa cell layer in healthy follicles, and to a lesser extent in theca cells, which is in agreement with greater mRNA abundance in granulosa cells. Strong staining in the cytoplasm of granulosa cells may also reflect binding of FGF17 to receptors (FGFR2C and FGFR3C; Berisha et al. 2004, Buratini et al. 2005b) and internalization. This is supported by evidence for receptormediated internalization of exogenous FGFs in several cell lines (Belleudi et al. 2002, Olsnes et al. 2003, Wesche et al. 2006). Therefore, the staining pattern combined with mRNA data suggests an autocrine action for FGF17 in granulosa cells within the follicle wall. Detection of FGF17 appears to be specific as preincubation of the antibody with FGF17 abolished staining, although we cannot rule out the possibility that the antibody reacts with other bovine FGFs.

Granulosa and theca cell abundance of FGF17 mRNA was significantly increased in atretic follicles compared with
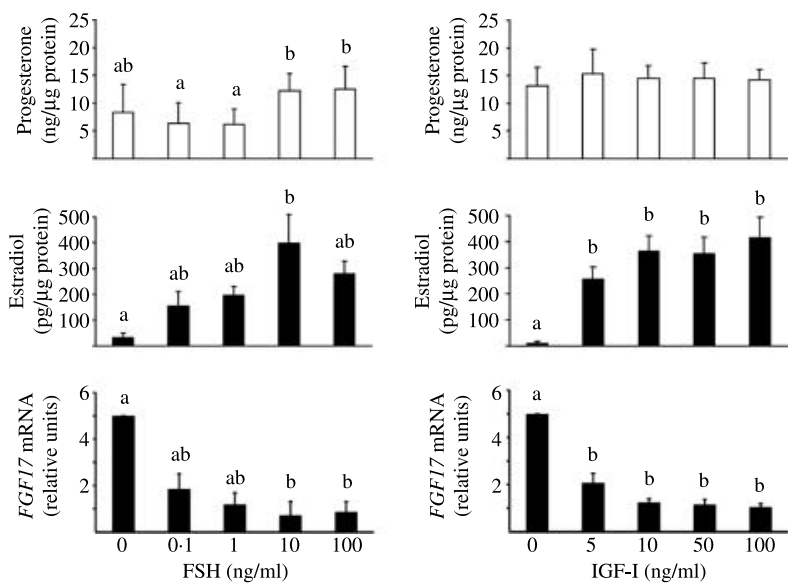

Figure 3 Effects of FSH and IGF-I on FGF17 mRNA abundance and steroid secretion in granulosa cells. Cells from follicles 2 to $5 \mathrm{~mm}$ diameter were placed in serum-free culture, and the stated doses of FSH or IGF-I were added on day 2. Total RNA was collected on day 6 , and FGF17 mRNA abundance was measured by real-time PCR. Data are presented as mean $( \pm$ S.E.M.) values relative to a calibrator sample by the $\Delta \Delta C_{\mathrm{t}}$ method with efficiency correction. Steroid concentrations were measured by RIA on day 6 and expressed relative to total protein at the end of culture. Bars with different letters are significantly different $(P<0 \cdot 05)$. Data were derived from three independent cultures. 

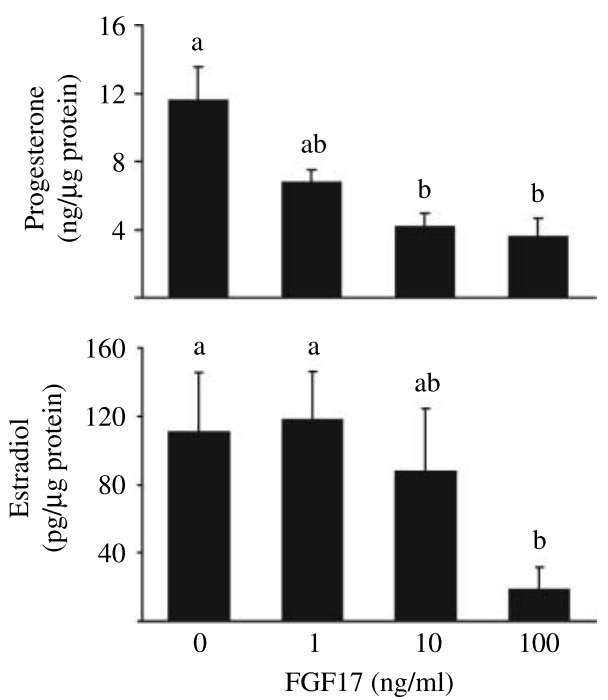

Figure 4 Effects of FGF17 on steroid secretion from granulosa cells. Cells from follicles 2 to $5 \mathrm{~mm}$ diameter were placed in serum-free culture and the stated doses of FGF17 were added on day 2. Media were collected on day 6 for measurement of steroid concentrations by RIA. Data are presented as mean ( \pm s.E.M.) values and expressed relative to total cell protein. Bars with different letters are significantly different $(P<0 \cdot 05)$. Data were derived from three independent cultures.

healthy follicles. FGF17 protein staining was also strong in the granulosa layer in atretic follicles. It is not known whether this is part of an apoptotic pathway or disregulation of gene expression during cell death. There was no effect of size on FGF17 expression in atretic follicles ranging from 5 to 11 $\mathrm{mm}$, suggesting that FGF17 expression is enhanced as nonovulatory dominant follicles and also non-selected recruited follicles enter atresia. This pattern of expression of FGF17 differs from that of FGF7 and FGF10: FGF10 mRNA abundance was significantly lower in atretic follicles compared with healthy follicles, whereas that of FGF7 did not change (Buratini et al. 2007). There is no information on the expression of other FGFs in atretic follicles.

As FGF17 mRNA and protein were both detected in granulosa cells, we determined whether the major gonadotropic hormones FSH and IGF-I regulate mRNA levels. Both hormones decreased FGF17 mRNA abundance while increasing $\mathrm{E}_{2}$ secretion, which is consistent with the low mRNA levels observed in healthy, estrogenic follicles. We are not aware of other reports describing the regulation of FGF expression by gonadotropins in granulosa cells, but microarray studies identified FGF2 and FGF5 as genes downregulated by FSH in the ovarian surface epithelium (Ji et al. 2004). It has been proposed that genes downregulated by FSH in granulosa cells are those primarily involved in cell cycle control and apoptosis (Sasson et al. 2003), again suggesting a role for FGF17 in atresia. Therefore, the ability of FSH and IGF-I to suppress FGF expression may significantly account for their wellestablished pro-survival action in antral follicles.
To explore the function of FGF17, we cultured bovine granulosa cells in serum-free medium with recombinant FGF17. In this estrogenic cell model, FGF2 and 10 have been demonstrated to inhibit $\mathrm{E}_{2}$ secretion (Cao et al. 2006, Buratini et al. 2007), and we show here that FGF17 has a similar effect. Interestingly, FGF2 was more potent at inhibiting $\mathrm{E}_{2}$ secretion than $\mathrm{P}_{4}$ secretion (Vernon \& Spicer 1994, Cao et al. 2006), whereas in the present study FGF17 was more potent at suppressing $\mathrm{P}_{4}$ secretion; $\mathrm{E}_{2}$ secretion was inhibited only at higher doses of FGF17. This suggests that while all FGFs studied to date inhibit steroidogenesis in bovine granulosa cells, they display different specificities for estrogenic and progestagenic pathways. Potential mechanisms of this differential action have not been investigated, but are likely related to mitogenactivated protein kinase (MAPK) activity; FGFRs activate the MAPK pathway (Powers et al. 2000), and MAPK activity suppresses aromatase (CYP19A1) mRNA expression (Silva \& Price 2000, Fan et al. 2009). As it would be critical to keep FGF17 levels low to allow $\mathrm{E}_{2}$ secretion and continued follicle growth, it is possible that FSH and IGF-I may stimulate $\mathrm{E}_{2}$ production in part through the inhibition of FGF expression.

In conclusion, the present study suggests a physiological role for FGF17 in the control of granulosa cell differentiation. FGF17 suppressed steroid secretion from granulosa cells, and mRNA abundance was decreased by FSH and IGF-I. This is consistent with lower FGF17 mRNA levels in healthy compared with atretic follicles. One potential role for FGF17 may be to inhibit $\mathrm{E}_{2}$ secretion and follicle growth in regressing follicles; therefore, it may be critical for FSH and IGF-I to suppress FGF17 expression during growth of the dominant follicle.

\section{Declaration of interest}

The authors declare that there is no conflict of interest that could be perceived as prejudicing the impartiality of the research reported.

\section{Funding}

This work was supported by the Fundação de Amparo à Pesquisa do Estado de São Paulo (FAPESP), Brazil, and the Natural Sciences and Engineering Research Council of Canada (NSERC).

\section{Acknowledgements}

We thank Dr J F Garcia (Universidade Estadual Paulista, Araçatuba) for sequencing the FGF17 PCR products, and Drs A C S Castilho, P Pinczowski, and D M Guerra for their technical assistance.

\section{References}

Bélanger A, Couture J, Caron S \& Roy R 1990 Determination of nonconjugated and conjugated steroid levels in plasma and prostate after separation on C-18 columns. Annals of the New York Academy of Sciences 595 251-259.

Belleudi F, Ceridono M, Capone A, Serafino A, Marchese C, Picardo M, Frati L \& Torrisi M 2002 The endocytic pathway followed by the keratinocyte growth factor receptor. Histochemistry and Cell Biology 118 1-10.

Berisha B, Schams D, Kosmann M, Amselgruber W \& Einspanier R 2000 Expression and localisation of vascular endothelial growth factor and basic fibroblast growth factor during the final growth of bovine ovarian follicles. Journal of Endocrinology 167 371-382. 
Berisha B, Sinowatz F \& Schams D 2004 Expression and localization of fibroblast growth factor (FGF) family members during the final growth of bovine ovarian follicles. Molecular Reproduction and Development 67 162-171.

Buratini J Jr, Glapinski VF, Giometti IC, Teixeira AB, Costa IB, Avellar MC, Barros CM \& Price CA 2005a Expression of fibroblast growth factor-8 and its cognate receptors, fibroblast growth factor receptor (FGFR) $3 \mathrm{c}$ and- 4 , in fetal bovine preantral follicles. Molecular Reproduction and Development $\mathbf{7 0}$ 255-261.

Buratini J Jr, Teixeira AB, Costa IB, Glapinski VF, Pinto MGL, Giometti IC, Barros CM, Cao M, Nicola ES \& Price CA 2005b Expression of fibroblast growth factor- 8 and regulation of cognate receptors, fibroblast growth factor receptor (FGFR)-3c and -4 , in bovine antral follicles. Reproduction $130343-350$.

Buratini J Jr, Pinto MG, Castilho AC, Amorim RL, Giometti IC, Portela VM, Nicola ES \& Price CA 2007 Expression and function of fibroblast growth factor 10 and its receptor, fibroblast growth factor receptor $2 \mathrm{~B}$, in bovine follicles. Biology of Reproduction 77 743-750.

Cao M, Nicola E, Portela VM \& Price CA 2006 Regulation of serine protease inhibitor- $\mathrm{E}_{2}$ and plasminogen activator expression and secretion by follicle stimulating hormone and growth factors in non-luteinizing bovine granulosa cells in vitro. Matrix Biology 25 342-354.

Fan H-Y, Liu Z, Shimada M, Sterneck E, Johnson PF, Hedrick SM \& Richards JS 2009 MAPK3/1(ERK1/2) in ovarian granulosa cells are essential for female fertility. Science 324 938-941.

Ford-Perriss M, Abud H \& Murphy M 2001 Fibroblast growth factors in the developing central nervous system. Clinical and Experimental Pharmacology and Physiology 28 493-503.

Grimes RW \& Ireland JJ 1986 Relationship of macroscopic appearance of the surface of bovine ovarian follicles concentrations of steroids in follicular fluid, and maturation of oocytes in vitro. Biology of Reproduction 35 725-732.

Gutiérrez CG, Campbell BK \& Webb R 1997 Development of a long-term bovine granulosa cell culture system: induction and maintenance of estradiol production, response to follicle-stimulating hormone, and morphological characteristics. Biology of Reproduction 56 608-616.

Ireland J, Good T, Knight P \& Ireland J 1994 Alterations in amounts of different forms of inhibin during follicular atresia. Biology of Reproduction 50 1265-1276.

Itoh N \& Ornitz DM 2004 Evolution of the Fgf and Fgfr gene families. Trends in Genetics 20 563-569.

Jeong YJ, Choi HW, Shin HS, Cui XS, Kim NH, Gerton GL \& Jun JH 2005 Optimization of real time RT-PCR methods for the analysis of gene expression in mouse eggs and preimplantation embryos. Molecular Reproduction and Development 71 284-289.

Ji Q, Liu PI, Chen PK \& Aoyama C 2004 Follicle stimulating hormoneinduced growth promotion and gene expression profiles on ovarian surface epithelial cells. International Journal of Cancer 112 803-814.

Kiefer P \& Dickson C 1995 Nucleolar association of fibroblast growth factor 3 via specific sequence motifs has inhibitory effects on cell growth. Molecular and Cellular Biology 15 4364-4374.

Krejci P, Krakow D, Mekikian PB \& Wilcox WR 2007 Fibroblast growth factors 1, 2, 17, and 19 are the predominant FGF ligands expressed in human fetal growth plate cartilage. Pediatric Research 61 267-272.

Lafrance M \& Goff AK 1985 Effect of pregnancy on oxytocin-induced release of prostaglandin $\mathrm{F}_{2 \alpha}$ in heifers. Biology of Reproduction 33 1113-1119.

Lavranos TC, Rodgers HF, Bertoncello I \& Rodgers RJ 1994 Anchorageindependent culture of bovine granulosa cells: the effects of basic fibroblast growth factor and dibutyryl cAMP on cell division and differentiation. Experimental Cell Research 211 245-251.

Leibfried L \& First NL 1979 Characterization of bovine follicular oocytes and their ability to mature in vitro. Journal of Animal Science 48 76-86.

Silva JM \& Price CA 2000 Effect of follicle-stimulating hormone on steroid secretion and messenger ribonucleic acids encoding cytochromes P450 aromatase and cholesterol side-chain cleavage in bovine granulosa cells in vitro. Biology of Reproduction 62 186-191.

Nilsson E, Parrott JA \& Skinner MK 2001 Basic fibroblast growth factor induces primordial follicle development and initiates folliculogenesis. Molecular and Cellular Endocrinology 175 123-130.

O'Leary DD, Chou SJ \& Sahara S 2007 Area patterning of the mammalian cortex. Neuron 56 252-269.
Olsnes S, Klingenberg O \& Wiedlocha A 2003 Transport of exogenous growth factors and cytokines to the cytosol and to the nucleus. Physiological Reviews 83 163-182.

Ornitz DM, Xu J, Colvin JS, McEwen DG, MacArthur CA, Coulier F, Gao G \& Goldfarb M 1996 Receptor specificity of the fibroblast growth factor family. Journal of Biological Chemistry 271 15292-15297.

Parrott JA \& Skinner MK 1998 Developmental and hormonal regulation of keratinocyte growth factor expression and action in the ovarian follicle. Endocrinology 139 228-235.

Pfaffl MW 2001 A new mathematical model for relative quantification in real-time RT-PCR. Nucleic Acids Research 29 e45.

Polnaszek N, Kwabi-Addo B, Wang J \& Ittmann M 2004 FGF17 is an autocrine prostatic epithelial growth factor and is upregulated in benign prostatic hyperplasia. Prostate 60 18-24.

Powers CJ, McLeskey SW \& Wellstein A 2000 Fibroblast growth factors, their receptors and signaling. Endocrine-Related Cancer 7 165-197.

Ramakers C, Ruijter JM, Deprez RH \& Moorman AF 2003 Assumption-free analysis of quantitative real-time polymerase chain reaction (PCR) data. Neuroscience Letters 339 62-66.

Sasson R, Dantes A, Tajima K \& Amsterdam A 2003 Novel genes modulated by FSH in normal and immortalized FSH-responsive cells: new insights into the mechanism of FSH action. FASEB Journal 17 1256-1266.

Sheng Z, Lewis JA \& Chirico WJ 2004 Nuclear and nucleolar localization of $18-\mathrm{kDa}$ fibroblast growth factor-2 is controlled by C-terminal signals. Journal of Biological Chemistry 279 40153-40160.

Spicer LJ \& Stewart RE 1996 Interactions among basic fibroblast growth factor, epidermal growth factor, insulin, and insulin-like growth factor-I (IGF-I) on cell numbers and steroidogenesis of bovine thecal cells: role of IGF-I receptors. Biology of Reproduction 54 255-263.

Sugiura K, Su YQ, Diaz FJ, Pangas SA, Sharma S, Wigglesworth K, O’Brien MJ, Matzuk MM, Shimasaki S \& Eppig JJ 2007 Oocyte-derived BMP15 and FGFs cooperate to promote glycolysis in cumulus cells. Development 134 2593-2603.

Valve E, Penttila TL, Paranko J \& Harkonen P 1997 FGF-8 is expressed during specific phases of rodent oocyte and spermatogonium development. Biochemical and Biophysical Research Communications 232 173-177.

Vernon RK \& Spicer LJ 1994 Effects of basic fibroblast growth factor and heparin on follicle-stimulating hormone-induced steroidogenesis by bovine granulosa cells. Journal of Animal Science 72 2696-2702.

Webb R, Nicholas B, Gong JG, Campbell BK, Gutierrez CG, Garverick HA \& Armstrong DG 2003 Mechanisms regulating follicular development and selection of the dominant follicle. Reproduction 61 71-90.

Wesche J, Malecki J, Wiedlocha A, Skjerpen CS, Claus P \& Olsnes S 2006 FGF-1 and FGF-2 require the cytosolic chaperone Hsp90 for translocation into the cytosol and the cell nucleus. Journal of Biological Chemistry 281 11405-11412.

van Wezel IL, Umapathysivam K, Tilley WD \& Rodgers RJ 1995 Immunohistochemical localization of basic fibroblast growth factor in bovine ovarian follicles. Molecular and Cellular Endocrinology 115 133-140.

Zhan X, Hu X, Friedman S \& Maciag T 1992 Analysis of endogenous and exogenous nuclear translocation of fibroblast growth factor-1 in NIH 3T3 cells. Biochemical and Biophysical Research Communications 188 982-991.

Zhang X, Ibrahimi OA, Olsen SK, Umemori H, Mohammadi M \& Ornitz DM 2006 Receptor specificity of the fibroblast growth factor family. The complete mammalian FGF family. Journal of Biological Chemistry 281 15694-15700.

Zhong W, Wang QT, Sun T, Wang F, Liu J, Leach R, Johnson A, Puscheck EE \& Rappolee DA 2006 FGF ligand family mRNA expression profile for mouse preimplantation embryos, early gestation human placenta, and mouse trophoblast stem cells. Molecular Reproduction and Development 73 540-550.

Received in final form 5 June 2009

Accepted 17 June 2009

Made available online as an Accepted Preprint 17 June 2009 